\title{
Transition of biogenic coal-to-methane conversion from the laboratory to the field: a review of important parameters and studies
}

\author{
Authors: Katherine J. Davis and Robin Gerlach
}

NOTICE: this is the author's version of a work that was accepted for publication in International Journal of Coal Geology. Changes resulting from the publishing process, such as peer review, editing, corrections, structural formatting, and other quality control mechanisms may not be reflected in this document. Changes may have been made to this work since it was submitted for publication. A definitive version was subsequently published in International Journal of Coal Geology, [185, January 2018]. DO\#10.1016/..coal.2017.11.006.

Davis, KJ, R. Gerlach, "Transition of biogenic coal-to-methane conversion from the laboratory to the field: a review of important parameters and studies," International Journal of Coal Geology, 2018; 185:33-43. 


\title{
Transition of biogenic coal-to-methane conversion from the laboratory to the field: A review of important parameters and studies
}

Katherine J. Davis, Robin Gerlach

\begin{abstract}
Coalbed methane (CBM) is an important unconventional natural gas resource in the U.S. and around the world. Many of the CBM containing coal formations are home to microbial communities producing the gas by con-verting coal to methane. Biogenically produced $\mathrm{CBM}$ provides an opportunity for developing technologies to enhance the microbial processes and increase the recoverable gas. To transfer strategies for biogenic CBM en-hancement from small-scale laboratory studies to large-scale commercial applications in subsurface coal beds, there are several factors that should be considered to facilitate this transfer. Coal rank, chemistry and structure, formation water chemistry, as well as microbial communities can vary widely among coal formations, and matching these components in laboratory studies to each other and the coal bed of interest should be considered. More work is required to understand the effects of gas sorption, pressure, and water movement through coal formations on biogenic gas production. Additionally, methods for applying methane enhancement strategies in situ must be further investigated to develop commercial applications of enhanced microbial coalbed methane production.
\end{abstract}

Most subsurface coal beds contain at least two types of fossil fuel energy: coal and natural gas. The natural gas, also known as coalbed methane (CBM), is considered an unconventional gas resource and has been extracted commercially in the United States since the late 1980s (Strąpoć et al., 2011). Due to the potential of microbial coal-to-methane conversion, it has been suggested that technologies can be developed to enhance biological reactions producing CBM and increase the amount of natural gas available for extraction from coal beds (Colosimo et al., 2016; Park and Liang, 2016; Ritter et al., 2015).

To advance the potential of biogenic CBM enhancement in situ, la-boratory experiments and field investigations have been published by researchers in many regions of the world. These studies have focused on the microbial communities responsible for the coal-to-methane con-version, coal bed hydrology and geochemistry, and methane enhance-ment strategies. While the body of knowledge regarding biogenic CBM production and potential enhancement strategies has increased over the last several years, gaps still exist, inhibiting the transfer of bench-scale research to field-scale demonstrations and commercial in situ applications.
This review seeks to identify and discuss the parameters to be considered when transferring strategies for CBM enhancement devel-oped in the laboratory to prospective in situ conditions. Gaps in the understanding of these parameters will be addressed, and suggestions will be made for the next steps necessary to apply enhancement strategies in the field.

2. Overview of naturally occurring coalbed methane

\subsection{Coalbed methane extraction techniques}

Coalbed methane (CBM) is natural gas found in subsurface coal beds. Due to geological characteristics and recovery methods required for collection, $\mathrm{CBM}$ is categorized as an unconventional gas (McGlade et al., 2013). Conventional natural gas resources generally require wells exceeding $1500 \mathrm{~m}(5000 \mathrm{ft})$ deep for extraction. Most methane-produ-cing coal beds are $<600 \mathrm{~m}$ (2000 ft) deep and many $<150 \mathrm{~m}(500 \mathrm{ft})$ (U.S. Energy Information Administration, 2016). This results in a much lower cost for drilling CBM extraction wells compared to wells for conventional natural gas extraction (Ritter et al., 2015). While most of the gas in conventional gas formations is typically found in the free 




Fig. 1. Schematic of water and gas production from a typical CBM production profile showing the different phases of production.

Adapted from Nuccio, 2000 .

state within the pores of the formation, most CBM in subsurface coal beds is thought to be sorbed to the coal itself (Moore, 2012).

It is generally accepted that CBM exists in three states in coal beds: (i) a free state where methane molecules exist as gas or dissolved within cleats (fractures) or macropores of the coal structure, (ii) an adsorbed state where methane sorbs to the coal surface within coal micropores by physical (physisorption) or chemical (chemisorption) interactions, and (iii) an absorbed state where methane is held within the chemical structure of the coal itself (Busch and Gensterblum, 2011; Moore, 2012). It is believed that the majority of subsurface CBM is adsorbed, and the amount that can be adsorbed is dependent on the surface area of the pores rather than the pore volume (Milewska-Duda et al., 2000).

For commercial CBM extraction, wells are drilled into the coal beds of interest, and casings are generally screened in the methane-producing regions. To release the CBM adsorbed to the coal, water is pumped from the wells to reduce the hydrostatic pressure and allow the adsorbed gas to desorb (Meredith et al, , 2012; Rice and Nuccio, n. d). CBM extraction initially produces high volumes of water to release the adsorbed gas from the coal, and pumped water volumes decrease as gas production increases when the coal bed is dewatered (Fig. 1) (Moore, 2012; Nuccio, 2000). While CBM wells are typically less expensive to drill than wells in conventional natural gas formations, most conventional natural gas wells produce more gas per well lifetime than CBM wells (Ritter et al., 2015).

The extraction of CBM produces large volumes of low quality water. The typical CBM well in the Powder River Basin (PRB) of Wyoming and Montana (U.S.A.) produces an average of approximately $64,300 \mathrm{~L} /$ day (17,000 gal/day) (Rice and Nuccio, n.d). CBM production waters commonly have total dissolved solids (TDS) exceeding the $500 \mathrm{mg} / \mathrm{L}$ limit recommended for drinking water (U.S. EPA, 2015) and 1000-2000 mg/L maximum recommended for stock ponds or irrigation (Rice and Nuccio, n.d). The main dissolved ions contributing to the elevated TDS in most CBM formations are sodium, bicarbonate and chloride. While most CBM production waters are of better quality than water produced from conventional oil and gas wells, TDS in CBM production waters can range between 200 and $170,000 \mathrm{mg} / \mathrm{L}$. Thus, it is often necessary to treat the production water for surface discharge and irrigation uses or determine long-term storage solutions (Rice and Nuccio, n.d).
To treat CBM production waters to meet discharge or irrigation standards, the TDS must be reduced. The most commonly established desalination methods include pressure driven techniques using membrane technologies or thermal treatments (Silva et al., 2017). The most effective pressure driven membrane technology ( $99 \%$ TDS removal efficiency) is reverse osmosis, which requires significant energy inputs to maintain the pressure gradient required for TDS removal (Ahmadun et al., 2009; Alzahrani and Mohammad, 2014). Thermal processes also require high energy and capital costs to effectively remove TDS which can make these methods cost-prohibitive (Silva et al., 2017). Some of the newer emerging membrane technologies used to treat production waters and effective for TDS removal include membrane distillation, forward osmosis, and pervaporation technologies which have been tested for treating CBM production water for irrigation applications (Silva et al, 2017). With up to $99.8 \% \mathrm{NaCl}$ removal and low energy requirements, pervaporation shows promise as a lower cost treatment method for CBM production water reuse (Sule et al,, 2013).

In addition to the large quantities of water produced during CBM extraction, CBM wells typically have a short lifespan of only 7-10 years resulting in a need for new well development on shorter time intervals than for conventional gas wells (Meredith et al., 2012). Despite these issues with CBM extraction, there are also benefits to using CBM for electricity generation instead of the coal itself.

Natural gas is considered a cleaner energy resource than coal, producing negligible amounts of mercury and sulfur compounds and approximately half the $\mathrm{CO}_{2}$ per unit of energy generated. In addition to higher $\mathrm{CO}_{2}$ emissions, combustion of coal results in approximately $450 \%$ more $\mathrm{NO}_{\mathbf{x}}, 500 \%$ more $\mathrm{CO}$, and $400 \%$ more particulate emissions compared to the combustion of natural gas (U.S. Energy Information Administration, 2017a, 2017b). These advantages of natural gas for electricity generation relative to coal suggest similar advantages for CBM. CBM extraction instead of coal mining in gas-producing coal beds would allow for the utilization of a potential energy source while reducing many harmful emissions, hazards of traditional coal mining, and the environmental impact caused by mining coal.

The U.S. has large reserves of both coal and natural gas (Tables 1 and 2) (U.S. Energy Information Administration, 2017a, 2017b), but the demonstrated coal reserves contain approximately five orders of magnitude more energy than natural gas reserves in the U.S. (U.S. Energy Information Administration, 2017c). However, only $\sim 4 \%$ of the total demonstrated coal reserve and $\sim 2 \%$ of the underground coal reserve bases are estimated to be recoverable with current infrastructure and active mines. These vast unmineable underground coal reserves provide sources of potential CBM extraction and opportunities for biogenic methane enhancement technology applications to increase recoverable CBM.

\subsection{Origins of CBM}

CBM can be formed in two ways. (i) Thermogenic methane is formed through abiotic processes requiring heat, pressure, and geological time scales; it is formed during the coal aging process and results from the thermally-induced conversion of larger coal molecules (Moore, 2012; Stolper et al, 2015). (ii) The second pathway for CBM formation is the conversion of coal to methane by microbial processes and is continually occurring in many coal formations (Park and Liang, 2016;

Table 1

Summary of US. estimated cosl reserves in 2015 (in million metric tons) (U.S. Energy Information Administration, 2017b)

\begin{tabular}{llll}
\hline & Demonstrated reserve base & Estimated recoverable reserves & Recoverable reserves at producing mines \\
\hline Underground - mineable coal & 297,367 & 133,161 & 6459 \\
Surface - mineable cosl & 135,431 & 98,077 & 10,167 \\
Total & 432,798 & 231,238 & 16,626 \\
\hline
\end{tabular}


Table 2

Summary of U.S estimated natural gas reserves in 2015 reserves (in billion cubic meters) (U.S. Energy Information Administration, 2017a).

\begin{tabular}{ll}
\hline & Reserves (billon $\mathrm{m}^{3}$ ) \\
\hline Wet NG & 9183 \\
Wet nonassociated NG & 7329 \\
Wet associated-dissolved NG & 1855 \\
Dry natural gas & 8714 \\
\hline
\end{tabular}

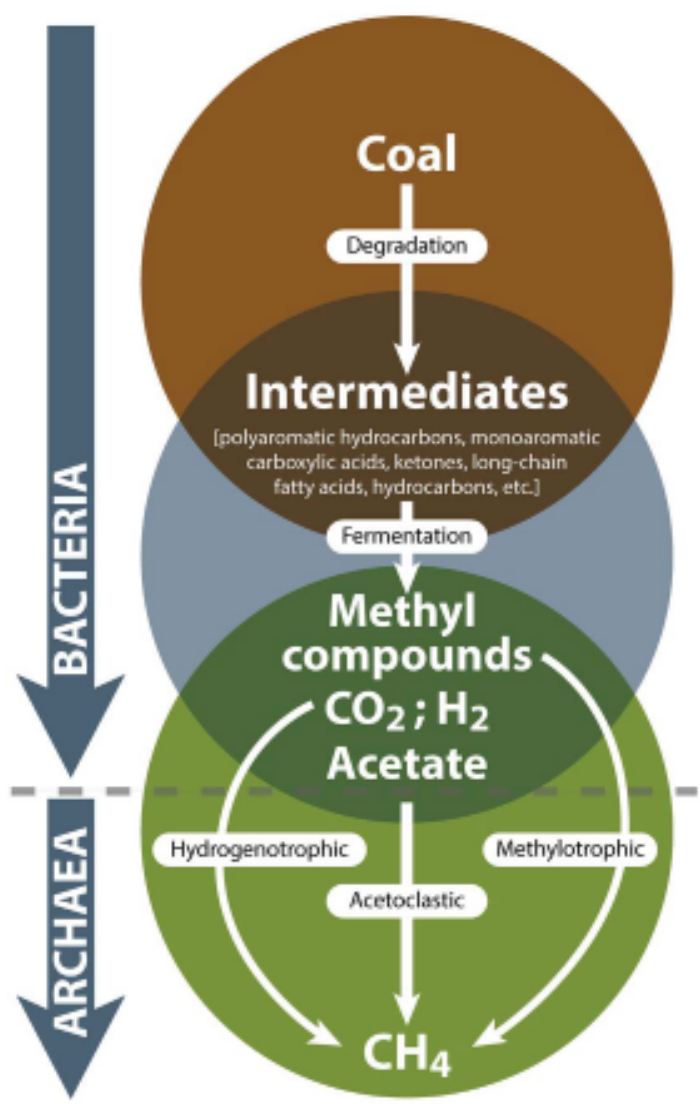

Fig. 2. Schematic of the sequential microbial degradation of cosl to produce coslbed methane (Moore, 2012; Schink, 2005; Strappot et al., 2011).

Ritter et al., 2015). Recently published articles provide detailed reviews of the microbial processes involved in biogenic CBM production, coal structure, and potential intermediates of biodegradation (Colosimo et al., 2016; Park and Liang, 2016; Ritter et al., 2015; Strąpoć et al., 2011).

In brief, the multi-step process of biogenic coal-to-methane conversion involves diverse microbial consortia containing both bacterial and archaeal members. It is generally accepted that bacteria sequentially break down the complex carbon in coal to intermediate and simple byproducts (Colosimo et al., 2016; McInerney et al., 2008; Schink, 2005). Some of the simplest byproducts of the bacterial biodegradation of coal are the substrates required by methanogenic archaea to produce methane gas (Fig. 2). In addition to bacterial coal degraders, recent studies have shown that fungi may also play a significant role in coal degradation to form methanogenic substrates (Guo et al., 2017; Haider et al., 2013).

The three primary pathways for archaeal methane production are hydrogenotrophic (Eq. (1)), acetoclastic (Eq. (2)), and methylotrophic (Eq. (3)) reactions. The $\mathrm{H}_{2}$, acetate, and methanol (or methyl-group containing molecules) are the byproducts of the bacterial degradation of coal and the substrates for methanogenic archaea (Colosimo et al., 2016; Park and Liang, 2016; Strąpoć et al., 2011).

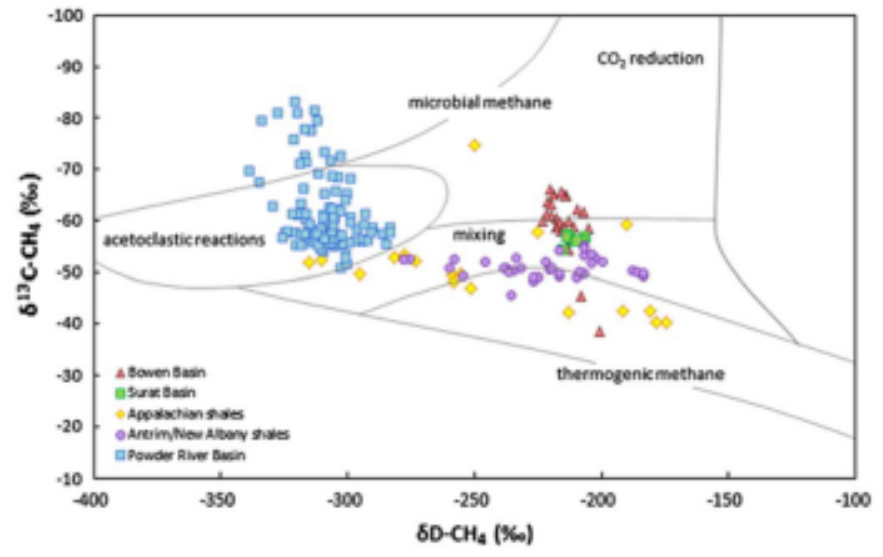

Fig. 3. Methane $\delta^{13} \mathrm{C}$ versus $\delta^{2} \mathrm{H}$ for several CBM and shale gas formations. The relationship between the two indicate varying origins of methane for different basins. Source Golding et al., 2013.

$\mathrm{CO}_{2}+4 \mathrm{H}_{2} \rightarrow \mathrm{CH}_{4}+2 \mathrm{H}_{2} \mathrm{O}$

$\mathrm{CH}_{3} \mathrm{COOH} \rightarrow \mathrm{CH}_{4}+\mathrm{CO}_{2}$

$4 \mathrm{CH}_{3} \mathrm{OH} \rightarrow 3 \mathrm{CH}_{4}+\mathrm{CO}_{2}+2 \mathrm{H}_{2} \mathrm{O}$

The gases found in coal beds can be thermogenic, biogenic or of mixed origin, and stable isotope analyses of produced gases have been used to determine gas origins. Most frequently, plots of $\delta^{13} \mathrm{C}-\mathrm{CH}_{4}$ versus $8 \mathrm{D}-\mathrm{CH}_{4}$ for CBM, as shown in Fig. 3, have been used to suggest the origins of produced gases and differentiate between the dominant biogenic pathways (Golding et al., 2013). Stable isotope analyses have been published for several CBM producing formations around the world. The Bowen and Surat Basins of Australia have isotopic signatures indicating that CBM is likely of mixed origins (Hamilton et al, 2014; Kinnon et al., 2010). The Forest City and Powder River Basins of the U.S. were found to have signatures indicative of almost exclusively biogenic CBM formation (Flores et al., 2008; McIntosh et al., 2008). While much of the methane found in Illinois Basin coal and shale formations have a thermogenic or mixed origin isotopic signature, several studies have shown that CBM produced along the eastern margins of this basin is primarily of biogenic origin and associated with meteoric groundwater recharge associated with glacial melting (Moore et al, 2016; Schlegel et al., 2011; Strąpoć et al., 2008, 2007). An Indonesian coal bed in the South Sumatra Basin has an isotopic signature suggesting mixed origin gas, and microbial communities found in this coal formation are indicative of the communities found in known biogenic CBM producing formations. Laboratory microcosms using formation water from this Indonesian coal bed produced biogenic methane (Susilawati et al., 2016).

A recent review by Vinson et al. (2017) raised questions about the accuracy of using conventional stable isotope analyses alone for the determination of gas origins or methanogenic pathways in coal and shale formations. Hydrogenotrophic methanogenesis is often predicted to be the dominant methanogenic pathway for biogenic CBM production when only conventional stable isotope analyses are considered. However, hydrogenotrophic methanogenesis can be indicated from stable isotope analysis, regardless of actual methanogenic pathways, due to hydrogen isotope equilibration between methane precursors and formation water. Additionally, improvements in microbial characterization studies have indicated the presence of methanogens capable of acetoclastic and methylotrophic methanogenesis (Vinson et al., 2017). The accuracy of analyses using $8^{13} \mathrm{C}$ measurements to predict $\mathrm{CBM}$ origins can be impacted by mixing of thermogenic and biogenic gases, competitive substrate conversion, methane oxidation, and formation water interactions. Thus, it is important to consider isotope fingerprints of coal basins with complementary microbial community analyses to obtain a more complete picture of the origins of coal bed gases (Vinson et al., 2017). 


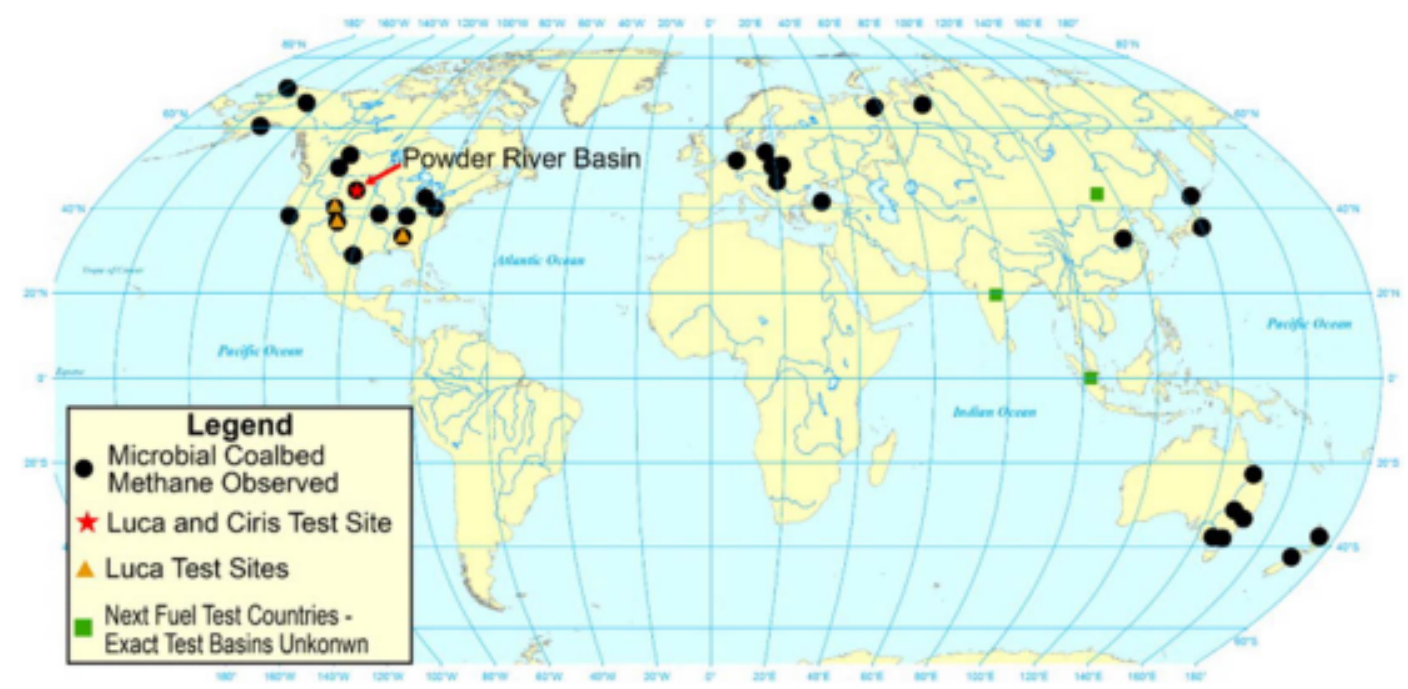

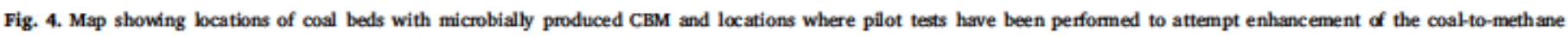
conversion.

Source: Ritter et al, 2015

CBM can be found in many locations around the world. While some CBM formations contain primarily thermogenic gases, many coal beds contain mixed origin methane, and the CBM of the Powder River Basin is thought to be solely of biogenic origin (Fig. 4) (Ritter et al., 2015). While CBM can be extracted from coal beds regardless of gas origin, biogenic production of CBM provides the potential to stimulate the microbial communities to increase the rates of coal-to-methane conversion, increase the extractable methane, and thus extend the life of inplace wells.

\subsection{Microbially enhanced coalbed methane (MeCBM)}

Strategies for enhancing microbially-produced CBM fall into three general categories: bioaugmentation, coal treatment to increase bioavailability, and biostimulation. Three recently published reviews (Colosimo et al,, 2016; Park and Liang, 2016; Ritter et al,, 2015) describe the most studied methods for enhancing biogenic CBM production, and the three most commonly pursued enhancement strategies are briefly summarized here.

Bioaugmentation is the addition of a coal degrading, methanogenic microorganisms to the coal environment and has been implemented in laboratory studies where biogenic coal-to-methane conversion was studied with non-coal sourced microbial consortia (Gupta and Gupta, 2014; Haider et al., 2013; Jones et al., 2010, 2008; Opara et al., 2012). While this strategy suggests the possibility of enhancing biogenic CBM in coal beds without current biogenic methane production, obtaining permits from regulatory agencies is likely difficult (Park and Liang, 2016; Ritter et al., 2015).

Coal treatment to increase its bioavalability for bacterial degradation is a second proposed strategy for enhancing biogenic CBM production. Hydraulic fracturing is a commonly used method for increasing surface area and releasing gases during shale gas extraction (Colosimo et al., 2016). Similar techniques could be applied in coal beds to release CBM and increase the surface area accessible for microbial degradation. However, fluids used for hydraulic fracturing could affect the native coal bed microbial community structure (Robbins et al., 2016b) or contaminate nearby drinking water aquifers (U.S. EPA, 2016). Strategies for pre-treating the coal have been studied in the laboratory; treatments include the use of strong oxidants such as hydrogen peroxide to increase coal bioavailability (Huang et al., 2013a; Jones et al., 2013), but, since strong oxidants are recommended for disinfection purposes (Centers for Disease Control and Prevention, 2016), these may also impact the microbial populations.
Another strategy for increasing the bioavailability of coal is the addition of biosurfactants or chemical surfactants to reduce surface and interfacial tensions between coal molecules to increase solubility (Colosimo et al., 2016). Biosurfactants produced by a strain of Pseudomonas stutzeri, isolated from an Indian coal bed, increased coal solubility in two ways: 1) improving contact between hydrophilic enzymes and hydrophobic coal surfaces and 2 ) increasing the solubility of coal humates by binding metals involved in ionic linkages (Singh and Tripathi, 2013). Increased biogenic methane production from coal was demonstrated for Surat Basin coals with the addition of the chemical surfactant Zonyl FSN (Papendick et al., 2011).

The most extensively investigated CBM enhancement strategy is biostimulation via nutrient addition. To apply biostimulation methods in situ or ex situ, a viable microbial consortium capable of coal-degradation and methanogenesis must be present. Some biostimulation studies have added methanogenic substrates (e.g. formate, acetate, $\mathrm{H}_{2}$ ) as nutrient amendments (Barnhart et al., 2013; Harris et al., 2008). These amendments were shown to increase methane production, but it is likely these additions were directly converted to methane and did not significantly increase the desired coal-to-methane conversion. Therefore, when choosing nutrients for addition, the target for stimulation should likely be the coal-degrading members of the community instead of the methanogens themselves.

Laboratory research to enhance coal degradation and thus increase coal-to-methane conversion have used synthetic nutrients $\mathrm{NH}_{4}{ }^{+}$, $\mathrm{K}_{2} \mathrm{HPO}_{4}$, trace minerals, vitamins) (Jones et al, , 2010; Zhang and Liang, 2017), yeast extract and/or peptones (Barnhart et al., 2017; Zhang et al., 2016), monosaccharides (Huang et al,, 2017), and biomass amendments (Bamhart et al., 2017; Davis et al., 2018). A few companies have made commercial attempts to enhance biogenic CBM production. Luca Technologies, Inc. applied its nutrient addition strategies at U.S. sites in the PRB (WY), Uinta Basin (UT), San Juan Basin (NM), and Black Warrior Basin (AL). The nutrient mixture included synthetic vitamins and minerals, complex nutrients like yeast extract and soy proteins, glycerol, and weak organic acids. Next Fuel, Inc. utilized nutrient additions containing synthetic, non-carbonaceous nutrients, trace metals, and vitamins at several sites in China, India and Indonesia. Cirus Energy attempted in situ biostimulation in the coal beds of the PRB using synthetic nutrients and yeast extract (Ritter et al., 2015).

While bioaugmentation, coal treatment, and biostimulation strategies have been tested extensively in the laboratory and have been applied commercially, transferring these methods to large-scale field applications faces several challenges, which are further discussed in this review. 


\section{Increasing field-relevance of laboratory biogenic CBM} enhancement strategies

Before applying laboratory-investigated MeCBM strategies in situ, several aspects should be considered. Bench-scale studies are greatly simplified representations of the subsurface coal environment, providing greater control of conditions, thus allowing for a better understanding of each step of coal-to-methane conversion. However, to scale up methane production enhancement strategies developed in the laboratory for application in the field, it is important to consider the design of ex situ experiments and how to account for differences between the laboratory and environmental conditions.

The subsurface coal environment can vary between coal beds in several ways. Formation water chemistry, coal type, native microbial consortium composition, pressure, and seepage velocity are some of the in situ variations to be considered when designing $\propto x$ situ laboratory experiments. While many bench-scale studies have demonstrated that enhancement strategies can significantly increases methane production, it is necessary to consider which laboratory conditions are representative of the coal environment of interest, which strategies can be economically applied in situ, and which require further investigation.

\subsection{Formation water chemistry}

Most subsurface coal aquifers contain elevated total dissolved solids (TDS) concentrations. Sodium, chloride and bicarbonate are the dominant species in CBM waters while concentrations of calcium, magnesium and sulfate are generally relatively low (Table 3). Compared to municipal drinking water, CBM formation waters can contain up to two orders of magnitude more sodium, chloride, and bicarbonate but can vary widely in concentration between formations. Sodium concentrations have been reported to range from $4.8-300 \mathrm{mmol} / \mathrm{L}$; chloride from 0.1-100 mmol// ; and bicarbonate from 6.9-300 mmol/L (Hamawand et al., 2013; Rice et al., 2000).

Most previously published bench-top studies of biogenic methane production have used synthetic media designed to imitate formation water. The same medium described by Tanner (2007) has, for instance, been used in laboratory studies of coals from the Surat Basin in Australia (Papendick et al., 2011), several coal beds from the Powder River Basin in Wyoming and Montana (USA) (Gallagher et al., 2013; Green et al., 2008; Harris et al., 2008), and the South Sumatra and Kutai Basins in Indonesia (Susilawati et al., 2013). While the use of synthetic media can remove some variability and can increase reproducibility, using the same medium recipe on coals originating in formations with different aquifer chemistries may not well represent the different in situ conditions, due to the wide variation in formation water composition observed (Table 3). While synthetic media can provide greater compositional control, formation water may contain (or lack) unknown essential or inhibitory trace compounds not added to the synthetic medium, or the medium may be more nutrient-rich than the in situ formation water. These differences can cause an over- or under-estimation of the in situ coal-to-methane conversion potential. Thus, it is important to consider variations in methane production in a laboratory setting due to the medium or formation water used in studies.

To address this concern and provide more in situ relevance to ex situ experiments, some CBM studies have used formation water in lieu of synthetic media in laboratory enrichments (Davis et al., 2018; Fallgren et al., 2013b, 2013a; Singh et al., 2012; Ulrich and Bower, 2008). By using formation water sourced from the coal bed of interest, concerns of chemistry differences between laboratory coal microcosms and the in situ conditions can be reduced.

\subsection{Microbial inocula for laboratory studies}

Microbial populations involved in coal degradation and methane production vary between coal basin location and between coal beds within a basin. Studies of the bacterial populations in the Powder River and Minois Basins in the U.S. and basins in Australia, Canada, and Japan have shown high relative abundances of the bacterial phyla Firmicutes and Proteobacteria (Barnhart et al., 2013; Colosimo et al., 2016; Green et al., 2008; Li et al., 2008; Penner et al., 2010; Shimizu et al., 2007). However, other dominant bacterial groups varied with PRB studies showing high abundances of Actinobacteria and Spirochaetes (Barnhart et al., 2013; Green et al., 2008) while the bacterial communities of the basins in Australia, Canada, and Japan showed higher abundance of Bacteroidetes. While there is bacterial similarity between methane-producing coal beds at the phylum level, differences in individual genera and species within these phyla contribute more variability between coal beds than is apparent from phylum level comparisons. (Li et al., 2008; Penner et al., 2010; Shimizu et al., 2007).

Archaeal methanogenic communities may also show differences between coal bed locations. While the most commonly found archaeal orders are Methanobacteriales, Methanomicrobiales, and Methanosarcinales, the dominant members are not consistent between locations. It was found in two PRB studies that members of the Methanosarcinales dominated the archaeal populations (Barnhart et al., 2013; Green et al., 2008). However, in an Indian coal bed, Methanomicrobiales and Methanobacteriales members dominated (Singh et al., 2012). These differences might suggest that the dominant methanogenic pathways may be different as Methanosarcinales have been described to be largely acetoclastic methanogens (Sowers et al., 1984) while Methanomicrobiales and Methanobacteriales appear to represent strictly hydrogenotrophic members (Kern et al., 2015; Yashiro et al., 2011). These variations in the apparent preferential methanogenic pathways suggest the presence of different metabolic pathways and potential differences in the bacterial populations involved in coal degradation.

In addition to these broad level comparisons between coal basins, Lawson et al. (2015) demonstrated that coal bed microbial community compositions can also vary significantly within the same coal basin. Microbial analyses of coal and formation water samples from 10 locations within the Alberta Basin (Canada) that varied in coal rank and depth-dependent physicochemical conditions showed differences in dominant taxa. While all samples contained Proteobacteria, Firmicutes,

Table 3

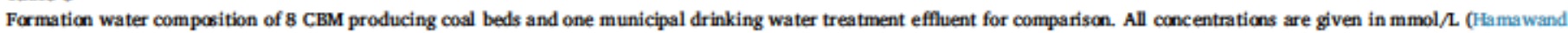
et al, 2013; Miller, 2016; Rice et al., 2000).

\begin{tabular}{|c|c|c|c|c|c|c|c|c|c|}
\hline & \multicolumn{4}{|c|}{ Bowen Basin, Australia } & \multicolumn{5}{|c|}{ U.S.A. } \\
\hline & Durham Ranch & Fairview & Upper seam & Lower seam & Black Warrior Basin & San Juan Basin & Uinta Basin & Powder River Basin & Municipal drinking water \\
\hline Calcium & 0.35 & 0.015 & 1.25 & 0.75 & 0.65 & 0.7 & 1.35 & $0.1-1.7$ & 0.548 \\
\hline Magnesium & 0.4 & 0.04 & 1 & 0.65 & 0.5 & 0.6 & 1.3 & $0.1-1.9$ & 1.323 \\
\hline Sodium & 100 & 11 & 100 & 100 & 70 & 300 & 160 & $4.8-33.9$ & 0.259 \\
\hline Chloride & 70 & 6 & 80 & 80 & 55 & 60 & 100 & $0.1-1.8$ & 0.169 \\
\hline Sulfate & 0.85 & 0.05 & 0.005 & 0.01 & 5 & 0.075 & 0.05 & $<0.2$ & 0.033 \\
\hline Bicarbonate & 12 & 10 & 10 & 20 & 10 & 300 & 70 & $6.9-38.0$ & 1.33 \\
\hline
\end{tabular}


and Spirochaetes, the predominant groups varied between coal beds, but all samples had microbial diversity indicating the potential for both coal degradation and methanogenesis (Lawson et al., 2015). It has also been shown that the microbial community composition can vary between coal and formation water samples from the same coal bed (Guo et al., 2012; Lawson et al., 2015; Wei et al., 2013). Additionally, Guo et al. (2012, 2015) compared microbial communities aerosolized in CBM gases to communities found in coal and production water samples from the same well in the Ordos Basin (China). It was shown that bacterial diversity was greater in the coal samples than in formation water or gas samples whereas the archaeal diversity was greater in formation water samples compared to coal or gas samples (Guo et al., 2015, 2012).

In laboratory studies, the source of the coal-degrading, methanogenic microbial consortium can significantly affect the ex situ experimental relevance to the in situ condition. Many CBM-related studies have used microbial consortia derived from non-coal sources such as wetlands, animal dung, anaerobic digester fluids, termite guts, and lake sediments (Gupta and Gupta, 2014; Opara et al., 2012; Robbins et al., 2016a). Jones et al. (2008) developed a bioassay to test methane potential of coal using the WBC-2 consortium that was derived from wetland sediments. Huang et al. (2013a, 2013b) used a Pseudomonas putida F1 strain to develop a bioassay to test coal bioavailability changes resulting from pretreatment with nitric acid $\left(\mathrm{HNO}_{3}\right)$, sodium hydroxide $(\mathrm{NaOH})$, potassium permanganate $\left(\mathrm{KMnO}_{4}\right)$, and hydrogen peroxide $\left(\mathrm{H}_{2} \mathrm{O}_{2}\right)$. Other studies have used microbial consortia from coal cores (Harris et al., 2008), pumped formation water (Papendick et al., 2011; Penner et al., 2010; Ulrich and Bower, 2008), or a specialized microbial sampler (Barnhart et al,, 2013). Microbial samples obtained with this sampler were shown to have higher cell counts and diversity than formation water alone (Barnhart et al., 2013). Building on the concepts of this microbial sampler, Barnhart et al. (2016a) developed a subsurface environmental sampler that can be deployed in CBM wells to collect microbial consortia native to both the coal and the formation water of interest. Because inoculum sourced from a methane-producing coal bed provides increased in situ relevance for laboratory experiments, this sampler provides a relatively low-cost solution for obtaining the microbial consortia native to the coal beds of interest. Selection of microbial consortia for laboratory coal-to-methane studies is an important consideration when transferring ex situ developed technologies to possible in situ applications.

\subsection{Coal source and treatment}

The source and treatment of coal used in bench-top experiments can also have implications for the transferability of laboratory results to in situ applications. Like the variations in microbial community composition and formation water chemistry observed between coal bed locations, coal itself can also vary between coal beds with differences in rank, permeability, elemental composition, ash content, and bioavailability (Bachu and Michael, 2003; Lawson et al., 2015; Scott, 2002; Strąpoć et al., 2011). While valuable information can be gained from studies sourcing coal, microbes, and formation water from different sources, maximal field relevance of laboratory experiments would be provided if coal, formation water, and microbial consortium were sourced from the same coal bed.

At the time of this review, only a few published studies are available, which use coal, microbes, and formation water from the same coal bed (Bi et al., 2017; Davis et al., 2018; Singh et al., 2012; Ulrich and Bower, 2008). One PRB study used coal and formation water from the Fort Union Formation coal bed and used microbes enriched from the formation water as inoculum to assess microbial metabolites (Ulrich and Bower, 2008). Singh et al. (2012) presented microcosm studies using coal and formation water from the Jharia coal field in eastern India to assess the methane-enhancement potential of the native consortium in the formation water. A frozen inoculum stock was developed from San Juan Basin (USA) coal and formation water and used in studies with coal and formation water from the same coal bed to study methane enhancement strategies (Bi et al., 2017). The work presented by Davis et al. (2018) used coal and formation water from the FlowersGoodale coal bed in the PRB and microbial consortia from the same coal bed obtained using a microbial sampler similar to the one described by Barnhart et al, (2013). To build on previous studies and transfer to field experiments, transitional studies should ideally be performed using coal, formation water and microbes from the same coal bed, if accessible and not cost prohibitive.

In addition to coal source, handling and treatment of coal samples for laboratory studies should also be considered. For studies focusing on microbial community composition, it is important to eliminate possible contaminants. Thus, some studies have used autoclaved coal in microcosm studies to ensure that the inoculum was the only microbial source (Singh et al., 2012; Susilawati et al., 2015, 2013; Wawrik et al., 2012). However, the autoclave process could result in chemical or physical changes in the coal structure (Watanabe et al., 2002) potentially causing changes in coal bioavailability. Thus, laboratory experiments using autoclaved coal, even when all the components are from the same coal bed, must consider the probable differences in methanogenic potential of the autoclaved coal when transferring to field applications in the same coal formation.

Some of the methane enhancement strategies tested in the laboratory include coal treatments for enhancing coal bioavailability. Horizontal drilling and hydraulic fracturing have been used to release gases from unconventional shale gas formations. These technologies increase the permeability of the formation and allow gases to be more easily recovered (Li et al., 2015). Many coal formations have low permeability and a dense matrix. Hydraulic fracturing has been shown to increase the permeability of subsurface coal beds by increasing the number of fractures in the coal matrix and improving coal dewatering for CBM recovery. While the cost-to-benefit ratio of hydraulic fracturing to increase methane production in coal beds has not yet been assessed, it has been proposed that similar fracturing technologies could potentially increase the bioavailable surface area in coal beds to increase biogenic CBM production (Colosimo et al,, 2016).

To test the hypothesis that increasing bioavailable coal surface area would increase biogenic methane production, laboratory studies have used sieved crushed coal and tested the biogenic methane production of each size fraction in microcosm studies. Green et al, (2008) used three separate coal sizes and found that the treatments with the smallest particles tested $(105-177 \mu \mathrm{m})$ produced the most methane but not statistically significantly more than the next size fraction tested (250-600 $\mu \mathrm{m})$. Papendick et al. (2011) also demonstrated the highest methane production with the smallest size fraction tested $(<300 \mu \mathrm{m})$ and similar methane production with coal sized at $300-600 \mu \mathrm{m}$ and $600-850 \mu \mathrm{m}$. Gupta and Gupta (2014) tested four coal fractions and found that the $30-60 \mu \mathrm{m}$ particle size produced the most methane, only slightly more than the smaller $15-30 \mu \mathrm{m}$ size but significantly more than the larger fractions tested. Another study also found that an intermediate coal particle size $(0.6-1.18 \mathrm{~mm})$ produced slightly more methane than both the smaller fraction (106-300 $\mu \mathrm{m})$ and larger fractions (3.35-4.75 $\mathrm{mm}$ and $6.3-9.5 \mathrm{~mm}$ ) (Davis, 2017). Thus, the published research on the effects of increasing coal surface area as a method for increasing biogenic CBM production show a possible effect of increasing methane production with increasing surface area. However, until more studies clearly indicate increased methane production with increased coal surface area, it cannot be concluded that hydraulic fracturing in coal beds is an economically viable solution for increasing biogenic methane production in coal beds.

In most laboratory studies, coal is dried and crushed before use in microcosm studies. Exposure to atmospheric oxygen may oxidize the coal and potentially change the bioavailability of the coal organic matter. Reduced biogenic methane production was demonstrated when coal was oxidized by exposure to atmospheric oxygen (Gallagher et al., 
2013). Another study showed increased methane production using the WBC-2 assay in microcosms containing potentially oxidized coal from dewatered coal beds when compared to coal from non-dewatered coal formations. This same study used a strong oxidant, hydrogen peroxide, to pretreat coal from three sources and showed increased methane production potential after peroxide oxidation (Jones et al., 2013). Coal pretreatment with another oxidant, potassium permanganate, was shown to increase methane production and dissolved organics compared to untreated coal (Huang et al,, 2013b, 2013a). While coal pretreatment with strong oxidants indeed appears to increase biogenic methane production, addition of these chemicals to subsurface coal beds introduces an added cost and may also affect the microbial community as strong oxidants are often used for disinfection (Centers for Disease Control and Prevention, 2016). Further studies are needed to assess the optimal amount of chemical for treatment, methods for application, detrimental effects on the microbial community, and a costbenefit ratio of these types of coal pre-treatments.

The type of coal used in experiments can affect the comparability and applicability of the laboratory studies to the coal subsurface environment. In addition, the pre-treatment of the coal in the laboratory can affect the methane production potential which could in turn affect the comparability of microcosm studies with in situ conditions. However, coal pre-treatment strategies proven to increase biogenic coal-to-methane conversion in the laboratory may be suitable for field application to enhance in situ CBM production if future investigations can show that the benefits of increased methane production exceed the costs of implementation and that microbial community structure is not detrimentally changed.

\subsection{Pressure}

Pressure is another environmental parameter to be considered in laboratory experiments and can vary significantly between coal beds due to depth and hydrostatic pressure. For example, two coal beds at a PRB field site (Barnhart et al,, 2016b) have estimated pressures between 690 and $1380 \mathrm{kPa}$ for wells screened at approximately 100 and $160 \mathrm{~m} \mathrm{(350} \mathrm{and} 530 \mathrm{ft}$, respectively) below ground surface (unpublished data). In the Ordos Basin, the reservoir pressure was measured at 2.58-12.22 MPa for coal formations with burial depths ranging from 455 to $1323 \mathrm{~m}$ (Zhao et al., 2016). Increased hydrostatic pressures have been shown to decrease microbial growth in deep-sea environments (Kaye and Baross, 2004; Marietou and Bartlett, 2014). While the pressures observed in most coal beds are less than in deep-sea environments, it can be hypothesized that decreased hydrostatic pressures in laboratory studies may alter microbial activity and community structure and thus the biogenic conversion of coal to methane. Perhaps of greater consequence, pressures can impact the sorption and solubility of methane, $\mathrm{CO}_{2}$, and other compounds in the subsurface coal beds and consequently affect the efficiency of produced methane quantification (Busch et al,, 2003; Merkel et al., 2015). Methods for measuring produced gases in laboratory experiments at atmospheric pressures do not adequately measure in situ gas production (Tang et al., 2017).

The most commonly used batch reactors for CBM studies are glass serum bottles which are set up at atmospheric pressure. Produced gases may increase the system pressure, but pressures in the serum bottles are still substantially less than in subsurface coal beds and therefore not representative of the in situ condition. Thus, it might be important to design laboratory systems that can withstand the higher pressures observed in the subsurface. Performing studies of biogenic CBM production at increased pressure will provide useful information to improve the design of field applications.

\subsection{Sarption of methane and $\mathrm{CO}_{2}$ to coal}

When biogenic coal-to-methane conversion is studied in the laboratory, methane production is almost always measured by sampling the microcosm headspace and measuring the concentration. This measurement does not take into account methane that is dissolved in the liquid or sorbed to the coal. The dissolved methane concentration can be estimated using Henry's Law assuming equilibrium conditions, but sorption of methane to coal is more difficult to quantify.

Coal sorption studies have shown preferential sorption of $\mathrm{CO}_{2}$ with a sorption capacity 2-4 times greater than for methane (Busch et al., 2003; Harpalani et al., 2006). Harpalani et al. (2006) state that the preferential sorption of $\mathrm{O}_{2}$ is influenced by the higher atmospheric boiling point of $\mathrm{CO}_{2}$ which results in higher sorption strength. In addition, $\mathrm{CO}_{2}$ can diffuse into smaller coal pores due to its smaller molecular diameter and thus can access more coal sorption sites not accessible to methane (Harpalani et al., 2006). Milewsla-Duda et al. (2000) demonstrated that absorption (sorption within the coal molecular structure) accounted for only a small fraction of the total methane sorption while it accounted for nearly half of the total $\bigodot_{2}$ sorption.

Most coal sorption studies have used dry coal to measure sorption and desorption isotherms. It has been shown that the rates of sorption are higher with dry coal, and that moisture in the coal reduces overall gas sorption capacity (Busch and Gensterblum, 2011; Merkel et al., 2015). Additionally, coal sorption isotherm studies have shown that sorption increases with increasing pressure (Busch et al., 2003; Harpalani et al., 2006; Merkel et al., 2015). Most laboratory CBM microcosms are studied at near-atmospheric pressure, and thus sorption in laboratory studies may not well-represent or predict sorption of biogenic CBM in situ. While some studies have addressed the potential effects of sorption on CBM production, it is likely that the sorption capacity, rates, and preferentially sorbed gases vary between coal sources (Busch et al., 2003). Thus, it can be difficult to determine how much total methane is produced in coal microcosms or in field studies because sorption rates and the amounts of sorbed methane or $\mathrm{CO}_{2}$ are challenging to estimate.

While there is still more work to be done to reliably quantify the amount of methane and $\mathrm{CO}_{2}$ sorbed to coal, the observed preferential sorption of $\mathrm{CO}_{2}$ has been proposed for enhanced $\mathrm{CBM}$ recovery while sequestering $\mathrm{CO}_{2}$ in coal beds (Gale and Freund, 2001; Ranathunga et al., 2014; Wen et al., 2017; White et al., 2005). When $\mathrm{CO}_{2}$ is injected into $\mathrm{CBM}$ containing coal beds, the $\mathrm{CO}_{2}$ will sorb to the coal and displace some of the previously sorbed CBM. Field applications of $\mathrm{CO}_{2}$ injection into coal beds have demonstrated enhanced CBM recovery by $\mathrm{CO}_{2}$ displacement of sorbed methane (Gunter et al,, 2004; Wong et al., 2007).

\subsection{Transitional labaratory systems}

Most previously published studies have investigated biogenic coalto-methane conversion in batch reactors. While these systems allow for greater control of the initial conditions, are easier to reproduce, and are relatively inexpensive, batch systems can be limited due to substrate depletion and/or by-product accumulation which can result in a cessation of microbial processes (Doran, 1995). These potential issues limit the transfer of methane enhancement strategies developed in batch systems to in situ applications and demonstrate the necessity for benchand meso-scale systems with greater field-relevance. To assess these issues with batch reactors, Zhang and Liang (2017) performed studies to assess nitrogen and phosphate limitation and by-product inhibition in both the headspace $\left(\mathrm{CH}_{4}\right.$ accumulation) and the liquid fraction. The results showed that coal appeared to still be bioavailable even after methane production stopped. Any substrate limitations appeared to be related to nitrogen and phosphate as methane production could be restimulated after production ceased by the addition of these key nutrients (Zhang and Liang, 2017).

Preventing atmospheric air infiltration to maintain an oxygen-free environment is one of the greatest challenges to running microbial coalto-methane studies in flow systems in the laboratory. Many members of coal-degrading, methanogenic microbial consortia have limited oxygen 
tolerance, and many members are considered to belong to anaerobic taxa (Colosimo et al., 2016; Kern et al., 2015; Parshina et al., 2014). Oxygen infiltration into the experimental system could change the community and the predominant metabolic pathways, potentially reducing the coal-to-methane conversion potential. In addition, it can be more difficult to achieve good reproducibility in flow systems than in batch systems as there can be variability in the coal packing of the reactors potentially resulting in preferential flow paths through the coal media as well as differences in flow rates due to pump variations.

Saturated subsurface coal formations have continuous flow with formation-specific (and possibly season-specific) seepage velocities (Barnhart et al., 2016b). In order to transfer benchtop batch system strategies to the field, it might be important to investigate stimulation methods in flow reactors. While flow reactors are more expensive to run, they do not have the challenges of substrate depletion or by-product accumulation, which are characteristic of batch reactors. A core flooding study investigated biogenic methane production in a coal system under pressure with continuous flow (Stephen et al., 2014). This study used synthetic media and ground the coal to a particle size of $<150 \mu \mathrm{m}$. The study was performed under a continuous flow of $0.006 \mathrm{~mL} / \mathrm{min}$ (seepage velocity could be estimated if reactor dimensions were known) and pressures ranging from 250 to $500 \mathrm{psi}$. Biogenic methane production was observed under both flow and higher than atmospheric pressure conditions.

Meslé et al. (2016) ran flow column studies using a pulse flow strategy at a pressure of approximately $550 \mathrm{kPa}(80 \mathrm{psi})$ using formation water, coal, and inoculum from PRB sources and produced biogenic methane in these coal systems. Davis (2017) designed an upflow column reactor that can separate produced gases for ease of measurement. This system was filled with $2-4 \mathrm{~mm}$ sized coal from the FlowersGoodale formation in the PRB. The formation water and microbial inoculum were also from the same coal formation. Methods for enhancing biogenic coal-to-methane conversion with algae amendment, previously tested in batch systems, were applied and resulted in increased methane production.

There is indeed evidence that flow systems might represent an important transitional step in the scale-up of field applicable MeCBM strategies. Because field applications can be costly and opportunities are limited, using laboratory-scale flow reactors might be an important step for determining the best practices to apply coal-to-methane enhancement strategies in subsurface coal beds.

\subsection{Enhancement of biogenic CBM with amendment additions}

Biogenic coal-to-methane conversion can be enhanced with nutrient additions. Some studies have demonstrated increased methane production with the addition of methanogenic substrates such as acetate, formate, methanol, methylamines, and $\mathrm{H}_{2}$ gas (Barnhart et al., 2013; Green et al., 2008; Harris et al., 2008; Wei et al., 2014). While biogenic methane production was increased in these studies, the carbon sources for increased methane production were likely the amendments and not the coal itself.

As discussed in recent reviews, for MeCBM biostimulation strategies to be economically viable, the addition of amendments should target the coal degraders to increase the rate of coal degradation and production of byproducts that become the substrates for methanogenesis (Colosimo et al., 2016; Ritter et al., 2015). Many of the published studies have provided macronutrients (ammonium, phosphate) and micronutrients (trace minerals, vitamins) in defined form in coal microcosms. Jones et al. (2010) used a nutrient-free medium, adding noncarbonaceous nutrients (N, P, K, trace minerals, vitamins) to only some treatments, and showed increased methane production with nutrient addition. Another study using non-carbonaceous nutrients (including ammonium, phosphate, and micronutrients) to enhance biogenic coalto-methane conversion showed a two- to four-fold increase in methane production from lignite sourced from a coal bed without detectable in situ biogenic CBM (Fallgren et al., 2013b).

The type and amounts of nutrients necessary for optimized methane production might be different for different coal beds. For example, Bi et al. (2017) developed a methane-enhancing nutrient recipe specific to a location in the San Juan Basin (USA). While the specific nutrient concentrations were not reported, the components tested to develop the nutrient recipe included electron donors, surfactants, organic solvents, carbon sources, and trace minerals. Addition of these nutrients resulted in a 24.3-fold increase in methane production during the first 30 days for microcosms with the nutrient recipe and coal compared to coal alone, demonstrating faster methane production and supporting the potential for overall increased methane production (Bi et al., 2017). The process of determining the necessary nutrients and optimized amounts can be difficult, time consuming, and costly. To address these concerns, the use of "multi-nutrients" has been introduced. Luca Technologies, Inc. used yeast extract, brewer's yeast, soy protein and peptones in its proprietary nutrient mix for enhancing biogenic CBM in situ (Ritter et al., 2015). In a recent publication, yeast extract and its common components, peptone, glutamate, and vitamins, were investigated for their effects on biogenic coal-to-methane conversion (Barnhart et al., 2017). Yeast extract had a greater enhancement effect than any of the individual components. In another study, tryptone was used as a methane-enhancing amendment and resulted in a 55-fold increase in methane production compared to coal alone (Penner et al,, 2010). Zhang et al. (2016) tested the concentration of yeast extract and trypticase peptones required for optimal methane enhancement and investigated alternative and potentially less expensive "multi-nutrients" including trypticase soy broth and corn steep liquor. These results support the use of complex nutrient sources for increasing biogenic methane production instead of investing the time and resources into determining the optimal individual nutrient composition needed for each coal bed.

In addition to yeast extract, Barnhart et al. (2017) tested the effects of lipid-extracted algal biomass as a methane-enhancing amendment. The algae-amended treatments showed increased methane production amounts and rates similar to the levels observed for yeast extractamended treatments. In a separate study, Davis et al. (2018) showed that algae, cyanobacteria, and yeast biomass, as well as commercial yeast extract, similarly enhanced biogenic coal-to-methane conversion when added at the same concentration in batch microcosms. The lower amendment concentration $(0.1 \mathrm{~g} / \mathrm{L})$ increased methane production 2.1 times compared to unamended coal treatments while the higher amendment concentration $(0.5 \mathrm{~g} / \mathrm{L})$ resulted in a 3.2 -fold increase for the 111-day study. Both amendment concentrations resulted in earlier onset of methane production and higher production rates (Davis et al., 2018). Phototrophic microalgae and cyanobacteria have the potential to be grown in production water holding ponds on or near the site where CBM enhancing amendments are to be applied in situ. In addition to providing a nutrient amendment for CBM enhancement, microalgae can produce lipids for biofuels and both algae and cyanobacteria can produce other high value chemicals or can be used as biofertilizer or aquaculture feedstock (Priyadarshani and Rath, 2012), and these other products could help offset the cost investment for CBM enhancement.

Another recent study proposed using simple carbohydrates derived from locally sourced forage crops or sugar beets for methane production in coal beds (Huang et al., 2017). While this study also proposes reducing methane production costs by using locally-sourced amendments, it is unclear from this study if these types of amendments enhance coalto-methane conversion or just provide an alternative carbon source for methane production that could be used more cost-effectively for methane production in above-ground anaerobic digesters.

A microalga, Neospongiococcum sp., was isolated from a CBM production water pond and has been shown to produce lipids when grown in production water with limited nutrient addition (Hodgsliss et al, 2016). Thus, it has been shown that algae and cyanobacteria can be 


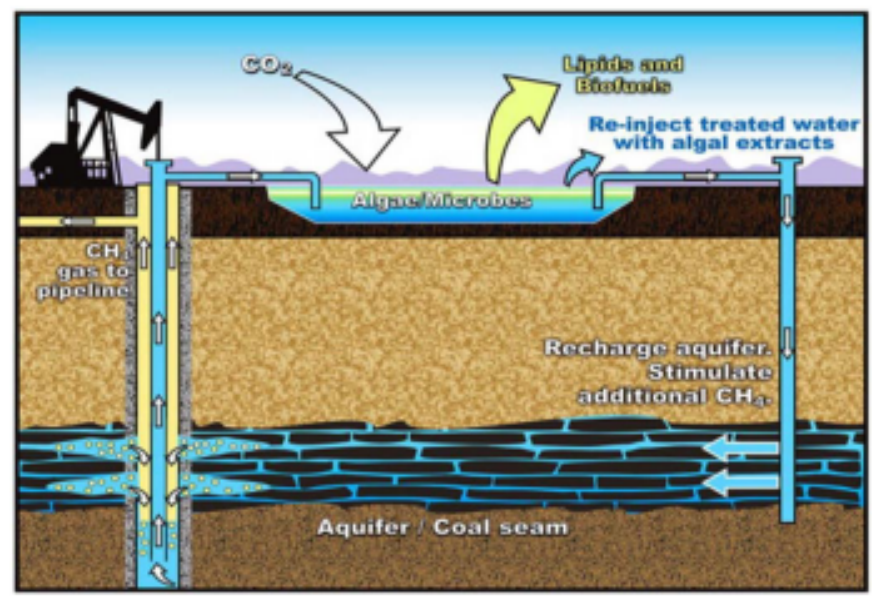

Fig. 5. Conceptual model of coalbed methane enhancement using algae. Algae fix atmospheric $\mathrm{CO}_{2}$ when grown in the production water ponds Lipids and other valuable products are harvested, and the residual biomass is used to enhance biogenic CBM production.

Source Bamhart et al, 2017.

used to enhance biogenic coal-to-methane conversion and at least one native strain of lipid-producing microalgae can be grown in CBM production water with limited nutrient addition. Fig. 5 shows a conceptual model of how the use of algae or cyanobacteria as a CBM enhancing amendment might be implemented. In addition, some of the costs associated with CBM enhancement could be reduced with this strategy by decreased amendment transport costs when the algae can be grown on site as well as off-set costs by producing other valuable and marketable algae-based products.

Strategies for delivery of subsurface amendments to enhance biogenic CBM production are still being researched. One strategy is to inject the algae (or other amendments) in an injection well while pumping water and harvesting CBM from a second well (Fig. 5) (Barnhart et al., 2017). A second strategy would be to use a "push-pull" method where the amendment is injected into the subsurface where it can enhance CBM production. After a certain amount of incubation time, water is pumped from the same well to extract CBM. To implement either strategy, the amount of amendment to be added must be considered based upon desired volume of coal to be impacted. Considerations must also be made to reduce the likelihood of clogging of the cleats and pores of the coal matrix by the added amendment or resulting microbial growth.

Most of the flow through a subsurface coal bed is through cleats (fractures) that generally have apertures of $<100 \mu \mathrm{m}$ (Laubach et al., 1998), but small amounts of liquid transport can also occur through the coal matrix itself. The porous coal matrix contains macropores (>50 nm), mesopores $(2-50 \mathrm{~nm})$, and micropores $(\leq 2 \mathrm{~nm})$ that are assumed to be too small for microbial access (Han et al., 2015). A typical cell size for Chlorella vulgaris, a much studied green microalga, ranges from 2 to $10 \mu \mathrm{m}$ (Milo, 2010). If the algae cells are not disrupted prior to amendment injection in the subsurface coal, the only flow path available to the algal amendment would be through the cleats. In addition, whole algal cells could block cleats that are smaller in diameter. Thus, processing of the algal amendment to break up the cells might be advantageous and result in smaller particle sizes, which would also likely increase the bioavailability of the nutrients to the microbial communities; however, it would also increase the cost of biogenic coalto-methane conversion.

\section{Conclusions}

Laboratory experiments investigating coal-to-methane conversion have produced a reasonable body of knowledge, and as a result, microbial communities and geochemistry in subsurface coal beds are better understood. Strategies for enhancing the microbial processes converting coal to methane have been developed in the laboratory and applied on fairly small scales in the field by several commercial ventures. However, due to the costs associated with applying CBM enhancement strategies in situ, it is important to consider the relatability of the laboratory studies to subsurface applications. To make ex situ studies as relevant to the subsurface condition as possible, the formation water, coal, and microbial consortium should be sourced from the coal formation of particular interest. This will ensure the best simulation of the subsurface environment. In addition, it is important to consider how the coal is processed for laboratory studies to minimize changes to the coal chemistry and potential bioavailability. Pressure differences between in situ coal conditions and laboratory studies should be considered for effects on both microbial processes and sorption of methane and $\mathrm{CO}_{2}$. In addition to pressure effects on methane and $\mathrm{CO}_{2}$ sorption, it is necessary to increase the understanding of competitive sorption and desorption of gases under saturated and unsaturated conditions and differences in sorption characteristics between different coal types. The effect of flow must not be discounted, and strategies for coal-to-methane conversion should be tested in flow reactors prior to application in situ. Lastly, methods for applying amendments for enhancing biogenic CBM production in the subsurface will require further research and development to ensure maximum enhancement with minimal costs associated with injection or long-term effects to water flow through the coal formation.

\section{Acknowledgements}

The authors would like to thank Joseph Parchen and Jill Story for their help with graphics and Matthew Fields, Brent Peyton, and Elliott Barnhart for their manuscript reviews. Support for this project was provided by the Department of Energy (DE-FE0024068) "Increasing the rate and extent of microbial coal to methane conversion through optimization of microbial activity, thermodynamics, and reactive transport" and NSFCHE-1230632 "SEP Collaborative: Alkaliphilic microalgae-based sustainable \& scalable processes for renewable fuels and products".

\section{References}

Ahmadun, F.-R., Pendashteh, A., Abdullah, L.C., Biak, D.R.A., Madaeni, S.S., Abidin, Z.Z, 2009. Review of technologies for oil and gas produced water treatment. J. Hazard. Mater. 170, 530-551. http://dx.doi.org/10.1016/j.jharmat.2009.05.044.

Alzahrani, S., Mohammad, A.W, 2014. Challenges and trends in membrane technology implementation for produced water treatment: a review. J. Water Process Eng 4, 107-133. http://dx.doi.org/10.1016/j.jwpe.2014.09.007.

Bachu, S., Michael, K, 2003. Possible controls of hydrogeological and stress regimes on the producibility of cosilbed methane in Upper Cretaceous-Tertiary strata of the Alberta basin. Cansda AAPG Bull 87, 1729-1754. http://dxdoiorg/10.1306/ 06030300015 .

Bamhart, E.P., De León, K.B., Ramsay, B.D., Cunningham, A.B., Fields, M.W., 2013. Investigation of coslassociated bacterial and archsesl populations from a diffusive microbial sampler (DMS). Int. J. Coal Geol. 115, 64-70. http://dx.doi.org/10.1016/j. cosal 2013.03.006.

Bamhart, E.P., Ruppert, L.F., Orem, W.H., Mcintosh, J.C., Ounningham, A.B., Fields, M.W., Hiebert, R., Hyatt, R, 2016a, Subsurface Environment Sampler for Improved In Situ Characterization of Subsurface Microbial Communities (PA21B-2206), in: GeoHeal th-Innovative Research at the Intersection of Geoscience and Health Science. Presented at the 2016 Fall Meeting. AGU, San Francisco.

Bamhart, E.P., Weels, E.P., Jones, E.J.P., Ritter, D.J., McIntosh, J.C., Clark, A.C., Ruppert, L.F., Cunningham, A.B., Vinson, D.S., Orem, W., Fields, M.W., 2016b.

Hydrogeochemistry and coal-associated bacterial populations from a methanogenic cosl bed. Int. J. Coal Geol. 162, 14-26. http:// dx.doi.org/10.1016/j.cosi.2016.05. 001.

Bamhart, E.P., Davis, K.J., Varonka, M., Orem, W., Cunningham, A.B., Ramsay, B.D., Fields, M.W., 2017. Enhan ced coal-dependent methanogenesis coupled with algal biofuels potential water recycle and carbon capture. Int. J. Coal Ged. 171, 69-75. http://dx doi.org/10.1016/j.cosl.2017.01.001.

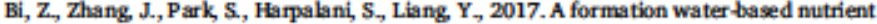
recipe for potentially increasing methane relesse from coal in situ. Fuel 209, 498-508. hittp://dx doi.org/10.1016/j.fuel.2017.08.008.

Busch, A., Gensterblum, Y., 2011. CBM and CO2-ECBM related sorption processes in cosl; a review. Int. J. CoslGeol. 87, 49-71. http://dx.doi.org/10.1016/j.cosl.2011.04.011.

Busch, A., Gensterblum, Y., Krooss, B.M., 2003. Methane and $\mathrm{CO2}$ sorption and 
desorption measurements on dry Argonne premium coals pure components and mixtures Int. J. Cosl Geol. 55, 205-224. http://dx.doi.org/10.1016/\$0166-5162(03) 00113-7.

Centers for Disease Control and Prevention, 2016. Guidelines for Disinfection and Sterilization of Healtheare Facilities. http:// www.cdc.gov/infectioncontrol/ guidelines/disinfection/disinfection-methods/chemical_html (accessed October 9, 2017).

Colosimo, F., Thomas, R., Lloyd, J.R., Taylor, K.G., Boothman, C., Smith, A.D., Lord, R, Kalin, R.M., 2016. Biogenic methane in shale gas and coal bed methane a review of current knowledge and gaps. Int. J. Cosl Ged. 165, 106-120. http://dxdoi.org/10. 1016/j.coal.2016.08 011 .

Davis, K.J., 2017. Organic Amendments for Enhancing Microbial Coalbed Methane Production (dissertation). Montana State University, Bozeman, MT.

Davis, K.J., Lu, S., Bamhart, E.P., Parker, A.E., Fields, M.W., Gerlach, R, 2018. Type and amount of organic amendments affect enhanced biogenic methane production from coal and microbial community structure. Fuel 211, 600-608. http://dx.doi.org/10. 1016/j. fuel .2017.09.074.

Doran, P.M., 1995. Bioprocess Engineering Principles, 1st ed. Academic Press Limited, London, UK

Fallgren, P.H., Jin, S., Zeng, C., Ren, Z., Lu, A., Colberg, P.J.S., 2013a Comparison of coal rank for enhanced biogenic natural gas production. Int. J. Coal GeoL 115, 92-96. $\mathrm{htty} / /$ dx.doi.org/10.1016/j.cosl.2013.01.014.

Fallgren, P.H, Zeng, C, Ren, Z, Lu, A., Ren, S., Jin, S, 2013b. Feasibility of microbial production of new natural gas from non-gas-producing lignite. Int. J. Coal Geol. 115, 79-84. http://dx.doi.org/10.1016/j.cos. 2013.03.003.

Flores, R.M., Rice, C.A., Stricker, G.D., Warden, A., Ellis, M.S., 2008. Methanogenic pathways of coslbed gas in the Powder River Basin, United States the geologic factor. Int. J. Cosl Ged. 76, 52-75. Microbes, Methanogenesis, and Microbial Gas in Cosl. https://doi.org/10.1016/.j.cosl 2008.02.005.

Gale, J., Freund, P., 2001. Coal-bed methane enhancement with $\mathrm{CO}_{2}$ sequestration workdwide potential. Environ. Geosci. 8, 210-217. http://dx.doi.org/10.1046/j. 1526-0984.2001.008003210.x.

Gallagher, L.K., Glosner, A.W., Landlkamer, L. L, Figueros, L.A., Mandemack, K.W., Munakata-Marr, J., 2013. The effect of cosl oxidation on methane production and microbial community structure in Powder River Basin cosl. Int. J. Cosl Ged. 115 , 71-78. http://dx.doi.org/10.1016/j.cosl.2013.03.005.

Golding, S.D., Boreham, C.J., Esterle, JS., 2013. Stable isotope geochemistry of cosl bed and shale gas and related production waters a review. Int. J. Cosl Geol 120, 24-40. http://dx doi.org/10.1016/j.cosL 2013.09.001.

Green, M.S., Flanegan, K.C., Gilcrease, P.C., 2008. Characterization of a methanogenic consortium enriched from a coslbed methane well in the Powder River Basin, USA. Int. J. Cosl Geol. 76, 34-45. htty//dx.doi.org/10.1016/j.coal.2008.05.001.

Gunter, W.D., Mavor, M.J., Robinson, J.R., 2004. $\mathrm{CO}_{2}$ Storage and Enhanced Methane production. Field Testing at Fenn-Big Valley, Alberta, Canada, With Application. Presented at the 7 th Intemational Conference on Greenhouse Gas Control Technology, Vancouver, Canada.

Guo, H., Liu, R., Yu, Z, Zhang, H., Yun, J., Li, Y, Liu, X., Pan, J., 2012. Pyrosequencing reveals the dominance of methylotrophic methanogenesis in a coal bed methane reservoir associated with Eastem Ordos Basin in China. Int. J. Cosl Ged. 93, 56-61. htty //dx.doi.org/10.1016/j.cosl.2012.01.014.

Guo, H., Yu, Z, Zhang, H., 2015. Phylogenetic diversity of microbial communities associated with coslbed methane gas from Eastern Ordos Basin, China. Int. J. Coal Geol. 150, 120-126. http://dx doi.org/10.1016/j.cosl.2015.08.012

Guo, H., Zhang, J., Han, Q., Huang, Z, Urynowicz, M.A., Wang, F, 2017. Important role of fungi in the production of secondary biogenic coalbed methane in China's southem Qinshui Basin. Energy Fuel 31, 7197-7207. http://dxdoi.org/10.1021/acs. energyfuels 7 bo0925.

Gupta, P, Gupta, A, 2014. Biogas production from cosl via anserobic fermentation. Fuel 118, 238-242. http://dxdoi.org/10.1016/j.fuel.2013.10.075.

Faider, R, Ghauri, M.A., SanFilipo, J.R., Jones, E.J., Orem, W.H., Tatu, C.A., Akhtar, K, Akhtar, N., 2013. Fungal degradation of cosl as a pretreatment for methane production. In: Fuel 10th Japan/China Symposium on Cosl and C1 Chemistry 104. Pp. 717-725. http://dx.doi.org/10.1016/j.fuel. 2012.05.015.

Hamawand, L. Yusaf, T., Hamawand, S.G., 2013. Coal seam gas and associated water a review paper. Renew. Sust. Energ Rev. 22, 550-560. http://dx.doi.org/10.1016/j rser. 2013.02.030.

Familton, S.K., Golding, S.D., Baublys, K.A., Esterle, J.S., 2014. Stable isotopic and molecular composition of desorbed coal seam gases from the Walloon Subgroup, eastem Surat Basin, Australia. Int. J. Cosl Geol. 122, 21-36. http://dx.doi.org/10.1016/j. coal. 2013.12.003.

Han, J., Yang, Z, Li, X., Zhang, J., 2015. Influence of cosl-seam water on coslbed methane production: a review. Chem. Technol. Fueb Oils 51, 207-221. http://dx.doi. org/10.1007/s10553-015-0594-9.

Harpalani, S., Prusty, B.K., Dutta, P., 2006. Methane/ $/ \mathrm{CO}_{2}$ sorption modeling for cosalbed methane production and $\mathrm{CO}_{2}$ sequestration. Energy Fuel 20, 1591-1599. http://dx. doi.org/10.1021/ef0504341.

Harris, S.H., Smith, R.L, Barker, C.E., 2008. Microbial and chemical factors influencing methane production in laboratory incubations of low-rank subsurface coak. Int. J. Cosl Geol. 76, 46-51. http://dxdoi.org/10.1016/1.cosl.2008.05.019.

Hodgskiss, L.H., Nagy, J., Bamhart, E.P., Cunningham, A.B., Fields, M.W., 2016. Cultivation of a native alga for biomass and biofuel accumulation in coal bed methane production water. Algal Res. 19, 63-68. http://dx.doi.org/10.1016/j.algal. 2016.07.014.

Huang, Z, Urynowicz, M.A., Colberg, P.J.S, 2013s. Stimulation of biogenic methane generation in coal samples following chemical treatment with potassium perman ganste. Fuel 111, 813-819. http://dx doi.org/10.1016/j.fuel 2013.03.079.

Huang, Z, Urynowicz, M.A., Colberg, P J.S., 2013b. Bicassay of chemically treated subbituminous cosal derivatives using Psaudamanas putida F1. Int. J. Coal Geol. 115, 97-105. http://dx.doi.org/10.1016/j.cosl.2013.01.012.

Huang, Z., Sednek, C., Urynowicz, M.A., Guo, H, Wang, Q., Fallgren, P., Jin, S., Jin, Y.,
Igwe, U., Li, S., 2017. Low carbon renewable natural gas production from caalbeds and implications for carbon capture and storage. Nat. Commun. 8, 568. http://dx.doi. org/10.1038/s41467-017-00611-7.

Jones, E.J.P., Voytek, M.A., Warwick, P.D., Corum, M.D., Cohn, A., Bunnell, J.E., Clark, A.C., Orem, W.H., 2008. Bioassay for estimating the biogenic methane-generating potential of cosl samples. Int. J. Cosal Geol 76, 138-150. http://dx.doi.org/10.1016/ i.cosi. 2008.05.011.

Jones, E.J.P., Voytek, M.A., Corum, M.D, Orem, W.H., 2010. Stimulation of methane generation from nonproductive coal by addition of nutrients or a microbial consortium. Appl Environ. Microbiol. 76, 7013-7022. http://dx.doi.org/10.1128/AEM. 00728-10.

Jones, E.J.P., Harris, S.H., Bamhart, E.P., Orem, W.H., Clark, A.C., Corum, M.D., Kirshtein, J.D., Varonka, M.S., Voytek, M.A., 2013. The effect of cosl bed dewatering and partial oxidation on biogenic methane potential Int. J. Cosl Geol. 115, 54-63. http://dx doi.org/10.1016/j.cosl.2013.03.011.

Kaye, J.Z, Baross, J.A., 2004. Synchronous effects of temperature, hydrostatic pressure, and salinity on growh, phospholipid profiles, and protein pattems of four Halomonos species isolated from deep-Sea hydrothermal vent and sea surface environments. Appl. Environ. Microbiol. 70, 6220-6229. http://dx.doi.org/10.1128/AEM.70.10. 6220-6229.2004.

Kern, T., Linge, M., Rother, M., 2015. Methanobacterim aggregans sp. nov., a hydrogenotrophic methanogenic archaeon isolated from an anserobic digester. Int. J. Syst. Evol. Microbiol 65, 1975-1980. http://dx doi.org/10.1099/ijs.0.000210.

Kinnon, E.C.P., Golding, S.D., Boreham, C.J., Baublys, K.A., Esterle, J.S., 2010. Stable isotope and water quality anslysis of cosl bed methane production waters and gases from the Bowen Basin, Australia. Int. J. Cosl GeoL 82, 219-231. https://doL.org/10. 1016/j.cosil.2009.10.014.

Laubach, S.E., Marrett, R.A., Olson, J.E., Scott, A.R., 1998. Characteristics and origins of coal cleat: A review. Int. J. Coal Geol. 35, 175-207.

Lawson, C.E., Strachan, C.R., Williams, D.D., Koxiel, S., Hallam, S.J., Budwill, K, 2015. Pattems of endemism and habitat selection in coslbed microbial communities. Appl. Environ. Microbiol. 81, 7924-7937. http://dx.doi.org/10.1128/AEM.01737-15.

Li, D., Hendry, P., Fatz, M., 2008. A survey of the microbial populations in some Australian coalbed methane reservoirs. Int. J. Coal Geol. 76, 14-24. https//doi.org/ 10.1016/j.cos . 2008.04.007.

Li, Q, Xing, H., Litu, J, Litu, X, 2015. A review on hydraulic fracturing of unconventional reservoir. Petroleum 1, 8-15. http://dx.doi.org/10.1016/j.petlm 2015.03.008.

Marietou, A., Bartlett, D.H., 2014. Effects of high hydrostatic pressure on cosstal bacteria community abundance and diversity. Appl. Environ. Microbiol 80, 5992-6003. http://dx.doi.org/10.1128/AEM.02109-14.

McGlade, C, Speirs, J., Sorrell, S., 2013. Unconventional gas - a review of regional and global resource estimates. Energy 55, 571-584. http://dx.doi.org/10.1016/j.energy. 2013.01.048.

McInerney, M.J., Struchtemeyer, CG., Sieber, J., Mouttakd, H., Stams, A.J.M., Schink, B. Rohlin, L., Gunsalus, R.P., 2008. Physiology, ecology, phylogeny, and genomics of microorganisms capable of syntrophic metabolism. Ann. N. Y. Acad. Sci. 1125, 58-72. http://dx doi.org/10.1196/annals. 1419.005.

MeIntosh, J., Martini, A., Petsch, S., Huang, R., Nïsslein, K, 2008. Biogeochemistry of the Forest City Basin coslbed methane play. Int. J. Coal Geol 76, 111-118. httpe//doi. org $/ 10.1016 / \mathrm{j}$.cosl.2008.03.004.

Meredith, E., Wheaton, J., Kurara, S., 2012. Coalbed methane basics ten years of lessons from the Powder River basin, Montana (information pamphlet no. 6). Mont. Bur. Mines Geol. http://mbmg.mtech.edu/pdf.publications/IP 6.pdf.

Merkel, A., Gensterblum, Y., Krooss, B.M., Amann, A., 2015. Competitive sorption of $\mathrm{CH}_{4}$, $\mathrm{CO}_{2}$ and $\mathrm{H}_{2} \mathrm{O}$ on natural coals of different rank. Int. J. Cosl Geol. 150-151, 181-192. http://dx.doi.org/10.1016/j.cosl.2015.09.006.

Mesłé, M., Phillips, A., Hodgskiss, L., Eldring, J., Hiebert, R., Cunningham, A., Fields, M. 2016. Design of a small-scale high pressure reactor system to study microbial bioconversion of coal to methane. In: Geologic Energy Research. Presented at the GSA Annual Meeting Denver, Colorado, U.S.A.. http://dx.doi.arg/10.1130/abs/2016.AM 285609 .

Milewska-Duda, J., Duda, J., Nodzeñski, A., Lakatos, J., 2000. Absorption and adsorption of methane and carbon dioxide in hard cosl and active carbon. Langmuir 16, 5458-5466. http://dx.doi.org/10.1021/1s991515s.

Miller, J., 2016. 2016 Water Quality Report (Annual Report). http://www.bozeman.net// home/showdocument?id $=2822$

Milo, R., 2010. Size - diameter - green algae Chbrella vulgaris - BNID 101481 [WWW document]. In: B10NUMB3R5 Database Useful Biol, Numbers. URL. http:// bionumbers.hms. harvard.edu/bionumber. aspo? id =1014818ver $=7$ (accesed 6.5.17)

Moore, T.A., 2012. Coalbed methane A review. Int. J. Coal Geol 101, 36-81. http://dx. doi.org/10.1016/j.coal.2012.05.011.

Moore, M T., Vinson, D. ., Darrah, T.H., 2016. Noble Gas, Hydrocarbon, and Nitrogen Isotopic Compositions of Coalbed Methane Reservoirs From the Illinois Basin, in: Unconventionsl Energy Resources. Presented at the Gedogical Society of America. Denver, Colorado, U.S.A.. http://dx.doi.org/10.1130/abs/2016AM-287715.

Nuccio, V., 2000. Coal-Bed Methane: Potential and Concerns In: U.S. Geological Survey Fact Sheet FS 123-00, . https://pubs usgs gov/fs/fs 123-00/\$123-00.pdf.

Opara, A., Adams, D.J., Free, M.L., MeLennan, J., Hamilton, J., 2012. Microbial production of methane and carbon dioxide from lignite, bituminous coal, and coal waste materiak. Int. J. Coal Geol. 96-97, 1-8. http: $/ /$ dx. doi.org/10.1016/j.cosi.2012.02 010.

Papendick, S.L., Downs, K.R, Vo, K.D., Familton, S.K, Dawson, G.K.W., Golding, S.D. Gilcrease, P.C., 2011. Biogenic methane potential for Surat Basin, Queendand coal seams. Int. J. Coal Geol 88, 123-134. http://dx doi.org/10.1016/..cosl.2011.09.005

Park, S.Y, Liang, Y., 2016. Biogenic methane production from caal a review on recent research and development on microbially enhanced cosllbed methane (MECBM). Fuel 166, 258-267. http://dx doi.org/10.1016/j.fuel.2015.10.121.

Parshina, S.N., Ermakova, A.V., Bomberg, M., Detkova, E.N., 2014. Methanospirillum stansii sp nov., a poychrotolerant, hydrogenotrophic, methanogenic archaeon 
isolated from an anserobic expanded granular sludge bed bioreactor operated at low temperature. Int. J. Syst. Evol. Microbiol. 64, 180-186. http://dx.doi.org/10.1099/ ijs. 0.056218-0.

Penner, T.J., Foght, J.M., Budwill, K., 2010. Microbial diversity of westem Canadian subsurface coal beds and methanogenic coal enrichment cultures. Int. J. Coal Geol 82, 81-93. http://dx.doi.org/10.1016/j.coal.2010.02.002.

Priyadarshani, L, Rath, B., 2012. Commercial and industrial applications of micro algae a review. J. Algal Biomass Util 3, 89-100. http://jalgalbiomass.com/ paper 14vol3no4.pdf.

Ranathunga, A.S., Perera, M.S.A., Ranjith, P.G., 2014. Deep coal seams as a greener energy source: a review. J. Geophys. Eng. 11, 063001. http://dx.doi.org/10.1088. $1742-2132 / 11 / 6 / 063001$

Rice C.A. and Nuccio V., Water produced with coslbed methane, In: U.S. Geological Survey Fact Sheet FS 156-00, https://pubs usgs.gov/fs/fs-0156-00/fs-0156-00. pdf.

Rice, C.A., Ellis, M.S., Bullock Jr., J.H., 2000. Water Co-Produced with Coalbed Methane in the Powder River Basin, Wyoming: Preliminary Compositional Data. http://www . blm.gov/style/medialib/blm/wy/programs/energy/og/cbmdocs/usgs ofr.Par.1659. Filedat/openfilerpt00_372.pdf.

Ritter, D., Vinson, D., Bamhart, E., Akob, D.M., Fields, M.W., Cunningham, A.B., Orem, W., McIntosh, J.C., 2015. Enhanced microbial coalbed meth ane generation: a review of research, commercial activity, and remaining challenges. Int. J. Coal Geol. 146, 28-41. http://dx.doi.org/10.1016/j.cosi.2015.04.013.

Robbins, S.J., Evans, P.N., Esterle, J.S., Golding, S.D., Tyson, G.W., 2016a. The effect of caal rank on biogenic methane potential and microbial composition. Int. J. Cosal Geol. 154-155, 205-212 http://dx.doi.org/10.1016/j.cos. 2016.01.001.

Robbins, S.J., Evans, P.N., Parks, D.H., Golding, S.D., Tyson, G.W., 2016b. Genomecentric analysis of microbial populations enriched by hydraulic fracture fluid ad. ditives in a cosl bed methane production well. Front. Microbiol 7. http://dx.doiorg/ 10.3389 /fmicb. 2016.00731.

Schink, B., 2005. Syntrophic associations in methanogenic degradation. In: Overmann, P.D.J. (Ed.), Molecular Basis of Symbiosis, Progress in Molecular and Subcellular Biology. Springer Berlin Heidelberg, pp. 1-19. htty//dx,doi.org/10.1007/3-54028221-1_1.

Schlegel, M.E., Zhou, Z., MeIntosh, J.C., Bal lentine, C.J., Person, M.A., 2011. Constraining the timing of microbial methane generation in an organic-rich shale using noble gases, Illinois Basin, USA. Chem. Geol. 287, 27-40. http://dx.doi.org/10.1016/j chemgeo.2011.04.019

Scott, A.R., 2002. Hydrogeologic factors affecting gas content distribution in cosl beds. Int. J. Coal Geol. 50 (50), 363-387. http://dx.doi.org/10.1016/S0166-5162(02) 00135-0.

Shimizu, S., Akiyama, M., Naganuma, T., Fujioka, M., Nake, M., khijima, Y, 2007 Molecular characterization of microbial communities in deep coal seam groundwater of northem Japan. Geobiology 5, 423-433. http://dx.doi.org/10.1111/.1472-4669. $2007.00123 x$.

Silva, T.L.S., Morales-Torres, S., Castro-Silva, S., Figueiredo, J.L., Silva, A.M.T., 2017. An overview on exploration and environmental impact of unconventional gas sources and treatment options for produced water. J. Environ. Manag. 200, 511-529. http:// dx.doi.org/10.1016/j.jenvman.2017.06.002

Singh, D.N., Tripathi, A.K, 2013. Coal induced production of a rhamnolipid biosurfactant by Pseudomonas sturzeri, isolated from the formation water of Jharia coalbed. Bioresour. Technol. 128, 215-221. http://dx.doi.org/10.1016/j.biortech.2012.10. 127

Singh, D.N., Kumar, A., Sarbhai, M.P., Tripathi, A.K, 2012. Cultivation-independent analysis of archaeal and bacterial communities of the formation vater in an Indian coal bed to enhance biotransformation of coal into methane. Appl Microbiol. BiotechnoL 93, 1337-1350. hitp://dxdoi.org/10.1007/300253-011-3778.1.

Sowers, K.R. Baron, S.F., Ferry, J.G., 1984. Methanosarcina acetivarats sp, nov, an acetotrophic methane-producing bacterium isolated from marine sediments. Appl. Environ. Microbiol. 47, $971-978$.

Stephen, A., Adebusuyi, A., Baldygin, A, Shuster, J., Southam, G., Budwill, K., Foght, J., Nobes, DS., Mitra, S.K., 2014. Bioconversion of cosl: new insights from a core flooding study. RSC.Adv. 4, 22779-22791. http://dx.doi.org/10.1039/C4RA01628A

Stolper, D.A., Martini, A.M., Clog, M., Douglas, P.M., Shusta, S.S., Valentine, D.L., Sessions, A.L., Eiler, J.M., 2015. Distinguishing and understanding thermogenic and biogenic sources of methane using multiply substituted isotopologues. Geochim. Cosmochim. Acta 161, 219-247. http://dx.doi.org/10.1016/1.gea.2015.04.015.

Strapoc, D., Mastalerz, M., Eble, C., Schimmelmann, A, 2007. Characterization of the origin of coslbed gases in southesstem Illinois Basin by compound-specific carbon and hydrogen stable isotope ratios. Org. Geochem. 38, 267-287. http://dx.doi.org/ 10.1016/j.orggeochem.2006.09.005.

Strapoc, D., Mastalerz, M., Schimmelmann, A., Drobniak, A., Hedges, S., 2008. Variability of geochemical properties in a microbially dominated coalbed gas system from the eastern margin of the Illinois Basin, USA. Int. J. Cosl Ged. 76, 98-110. https//doit org/10.1016/j.cosl.2008.02.002

Strapoc, D., Mastalerz, M., Dawson, K., Macalady, J., Callaghan, A.V., Wawrik, B., Turich, C., Ashby, M., 2011. Biogeochemistry of microbial coalbed methane. Annu. Rev. Earth Planet. Sci. 39, 617-656. http://dxdoi.org/10.1146/annurevearth-040610133343.

Sule, M., Jiang, J., Templeton, M., Huth, E., Brant, J., Bond, T., 2013. Salt rejection and water flux through a tubular pervaporative polymer membrane designed for irrigation applications Environ. Technol 34, 1329-1339. https//dxdolorg/10.1080/ 09593330.2012 .746736

Susilawati, R., Papendick, S.L., Gilerease, P.C., Esterle, JS., Golding, S.D., Mares, T.E. 2013. Preliminary investigation of biogenic gas production in Indonesian low rank coals and implications for a renewable energy source. J. Asian Earth Sci. 77, 234-242. http://dx.doi.org/10.1016/j.jseaes. 2013.08.024.

Susilawati, R., Evans, P.N., Esterle, J.S., Robbins, S.J., Tyson, G.W., Golding, S.D., Mares, T.E., 2015. Temporal changes in microbial community composition during culture enrichment experiments with Indonesian cask. Int. J. Coal Ged. 137, 66-76. http:// dx.doi.arg/10.1016/j.coal .2014.10.015.

Susilawati, R, Golding, S.D., Baublys, K.A., Esterle, JS., Hamilton, S.K., 2016. Carbon and hydrogen isotope fractionation during methanogenesis: a laboratory study using cosal and formation water. Int. J. Coal Geol. 162, 108-122. htty//dx. doi.org/10. 1016/j.cosal. 2016.05.003.

Tang, X, Ripepi, N., Stadie, N.P., Yu, L, 2017. Thermodynamic analysis of high pressure methane adsorption in Longmaxi shale. Fuel 193, 411-418. http://dxdoi.org/10. 1016/f.fuel.2016.12.047.

Tanner, R.S., 2007. Cultivation of bacteria and fungi. In: Manual of Environmental Microbiology. ASM Press, Washington, DC, pp. 69-78

U.S. Energy Information Administration, 2016. Average Depth of Crude Oil and Natural Gas Wells [WWW Document]. Pet. Liq. URL. https://Www.eis.gov/dnav/pet/pet. crd_welldep_s1_a.htm (accessed May 29, 2017).

U.S. Energy Information Administration, 2017a Natural Gas - U.S. Energy Information Administration (EIA) [WWW Document]. Nat. Gas URL. http://Www.eia.gov/ naturalgas/ (accessed January 13, 2017).

U.S. Energy Information Administration, 2017b. Coal - U.S. Energy Information Administration (EIA) [WWW Document]. Coal URL. https://Www.eia.gov/coal/ (accessed June 17, 2017)

U.S. Energy Information Administration, 2017c. Total Energy - US. Energy Information Administration (EIA) [WWW Document]. URL https//Www.eiagov/totalenergy/ (accessed October 6, 2017).

U.S. EPA, 2015. Secondary Drinking Water Standards Guidance for Nuisance Chemicals [WWW Document]. US EPA, URL https//www.epa.gov/dwstandardsregulations/ secondary-drinking-waterstandards-guidance-nuisance-chemicals (accessed July 10 , 2017).

U.S. EPA, 2016. Hydraulic Fracturing for Oil and Gas: Impacts from the Hydraulic Fracturing Water Cycle on Drinking Water Resources in the United States (Finst Repart) (Reparts \& Assessments No. EPA-600-R-16-236ES). U.S. Environmental Protection Agency, Washington, DC.

Ulrich, G., Bower, S., 2008 Active methanogenesis and acetate utilization in Powder River Basin coals, United States. Int. J. Coal Geol. 76, 25-33. Microbes, Methanogenesis, and Microbial Gas in Coal. https://doi.org/10.1016/j.cosal.2008.03. 006

Vinson, D.S., Blair, N.E., Martini, A.M., Larter, S., Orem, W.H., McIntosh, J.C., 2017 Microbial methane from in situ biodegradation of coal and shale: a review and re evaluation of hydrogen and carbon isotope signatures Chem. Geol. 453, 128-145. http://dx doi. org/10.1016/j.chemgeo. 2017.01.027.

Watanabe, L., Sakanishi, K., Mochida, L, 2002. Changes in coal aggregate structure by heat treatment and their cosl rank dependency. Energy Fuel 16, 18-22. http://dx.doi. org/10.1021/ef010144e.

Wawrik, B., Mendivelso, M., Parisi, V.A., Suflita, J.M., Davidova, L.A., Marks, C.R., Van Nostrand, J.D., Liang, Y., Zhou, J., Huizinga, B.J., Strapoc, D., Callaghan, A.V., 2012 Field and kaboratory studies on the bioconversion of cosl to methane in the San Juan Basin. FEMS Microbiol. Ecol 81, 26-42. http://dx.doi.org/10.1111/j.1574-6941. 2011.01272x.

Wei, M, Yu, Z, Zhang, H., 2013. Microbial diversity and abundance in a representative small-production cosl mine of Central China. Energy Fuel 27, 3821-3829. http://dx. doi.org/10.1021/ef400529f.

Wei, M., Yu, Z., Jiang, $\mathrm{Z}$., Zhang, $\mathrm{H}$, 2014. Microbial diversity and biogenic methane potential of a thermogenic-gas cosl mine. Int. J. Cosal GeoL 134-135, 96-107. http: / dx doi.arg/10.1016/f.cosl.2014.09.008.

Wen, H., Li, Z., Deng. J., Shu, C.-M., Laiwang, B., Wang, Q., Ma, L., 2017. Influence on cosl pore structure during liquid $\mathrm{CO}_{2}$-ECBM process for $\mathrm{CO}_{2}$ utilization. J. $\mathrm{CO}_{2}$ Util. 21, 543-552. http://dx.doi.org/10.1016/j.jcou. 2017.09.002.

White, C.M., Smith, D.H., Jones, K. L, Goodman, A.L., Jikich, S.A., LaCount, R.B., DuBose S.B., Ozdemir, E., Morsi, B.L, Schroeder, K.T., 2005. Sequestration of carbon dioxide in coal with enhanced coalbed methane recovery. a review. Energy Fuel 19, 659-724. http://dx.doi.org/10.1021/ef040047w.

Wong, S., Law, D., Deng, X., Robinson, J., Kadatz, B., Gunter, W.D., Jianping, Y., Sanli, F. Zhiciang, F., 2007. Enhanced coalbed methane and $\mathrm{CO}_{2}$ storage in anthracitic coals-Micro-pilot test at South Qinshui, Shanxi, China In: Int. J. Greenh. Gas Control. 8th International Conference on Greenhouse Gas Control Technologies 1. pp. 215-222. http://dx.doi.org/10.1016/\$1750-5836(06)00005-3.

Yashiro, Y, Sakai, S., Ehara, M, Miyazaki, M., Yamaguchi, T., Imachi, H., 2011. Methanaregula farmidica sp. nov, a methane-producing archaeon isolated from me thanogenic sudge. Int. J. Syst. Evol. Microbiol 61, 53-59. http://dx.doi.org/10. $1099 / \mathrm{ijs} .0 .014811-0$.

Zhang, J., Liang, $Y_{\text {, }}$ 2017. Evaluating approaches for sustaining methane production from cosl through biogasification. Fuel 202, 233-240. http://dxdoi.org/10.1016/j.fuel. 2017.04.037.

Zhang J., Park, S.Y, Liang Y., Harpalani, S., 2016. Finding cost-effective nutrient sohutions and evaluating environmental conditions for biogasifying bituminous coal to methane ex situ. Appl. Energy 165, 559-568. http://dx.doi.org/10.1016/j.apenergy. 2015.12.067.

Zhao, J., Tang, D., Xu, H., Li, Y., Li, S., Tao, S., Lin, W., Liu, Z., 2016. Characteristic of in situ stress and its control on the coalbed methane reservoir permesbility in the eastern margin of the Ordos Basin, China Rock Mech. Rock. Eng. 49, 3307-3322. http://dx doi.org/10.1007/300603-016-0969-1. 